PLATE I2.

Fig. I.-Livbunum vittatum. Female. Natural size.

2.-Parts of same. Magnified.

2a.-Body.

2b.-Eye eminence. Side view.

2c.-Eye eminence. Front view.

2d.-Palpus. Side view.

2e.-Claw of palpus. Side view.

PlAte I3.

Fig. I.-Liobunum ventricosum (Wood) male. Natural size.

2.-Parts of same. Magnified.

2a.-Body.

2b.-Eye eminence. Side view.

2c.-Eye eminence. Front view.

2d.-Palpus. Side view.

$2 e$. - Claw of palpus. Side view.

2f.-Maxillary lobe of second pair of legs.
PLATE I4.

Fig. 1.-Liobunum ventricosum hyemale. Immature. Natural size.

2.-Parts of same. Magnified.

$2 a$.-Body.

2b.-Eye eminence. Side view.

2c.-Eye eminence. Front view.

2d.-Palpus. Side view.

$2 e$. - Claw of palpus. Side view.

PLATE 15 .

Fig. I.-Liobunum politum magnum. Female. Natural size.

2.-Liobunum politum. Parts of male. Magnified.

2a.-Body.

2b.-Eye eminence. Side view.

2c.-Eye eminence. Front view.

2d.-Palpus. Side view.

$2 e$. - Claw of palpus. Side view.

\title{
DESCRIPTION OF A NEW AND INTERESTING PHASIID-LIKE GENUS OF TACHINIDAE S. STR.
}

\author{
BY C. H. TYLER TOWNSEND, LAS CRUCES, N. MEX.
}

During the last year, I have received, among several lots of flies from New Hampshire, a number of specimens of a tachinid s. str., which I at first mistook for a phasiid of the genus Hyalomyia. Upon examination, recently, the distinctness of the form was at once realized, but the great resemblance in almost every detail save one was very surprising. This one detail will, however, always be sufficient to distinguish it, and that is the presence of macrochaetae on the abdomen, a character possessed by no phasiid.

From its extreme resemblance to
Hyalomyia, I propose to call the new genus Hyalomyorles. The species may be known as 17 . weedii, in honor of Dr. Weed, in whose sendings my attention was first called to this interesting form.

\section{IIyALOMYODES nov, gen.}

Head much like Iryalomyia; front very narrow, slightly widened at vertex, much more widened toward insertion of antennae, at narrowest about one ninth width of head in both sexes. Face widening from front at same angle as latter, so that the two opposite boundaries of the face and front diverge uniformly from each other from the narrowest part of the front to a point very near the oral 
margin. Sides of face extremely narrow, cheeks but little wider, the eyes thus descending very nearly to oral margin. Oral margin distinctly protruded anteriorly, vibrissal angles situated distinctly above oral margin, facial ridges with only several small bristles above and immediately next to the vibrissae, which latter are not strong but are distinct from the row of other bristles below them, and slightly decussate. Antennae reaching a little more than half-way to the oral margin, third joint about once and a half as long as second. Arista bare, thickened on basal third, I-jointed at extreme base. Frontal bristles rather weak, descending only to insertion of antennae. Proboscis not long, moderately stout, labella developed; palpi filiform, very slender but elongate. Thorax distinctly narrower than head, with a few bristles; scutellum subtriangular, with three pairs of bristles. Abdomen broad roundovate, very distinctly wider than thorax, less broadened in $\delta$, vaulted, the tergum convex, venter almost always concave, furnished with rather numerous weak macrochaetae. Legs not stout, moderately long. Wings longer than abdomen, apical cell long petiolate, the petiole but little shorter than apical cross vein, fourth vein bent in a curve to third hardly more abruptly than in Hyalomyia. Hind cross vein nearly straight, longer than apical cross vein, nearer to small cross vein than to curve of fourth vein. Tegulae large, the upper scale about one fifth size of lower.

Hyalomyodes weedii nov. sp. Length of body, 4 to $4.5 \mathrm{~mm}$.; of wing, 3.5 to $4 \mathrm{~mm}$. Frontal vitta velvety black, taking up nearly all of front, widening behind and before with the width of front; the extremely narrowed sides of front, the sides of face and cheeks silvery white; facial depression silvery. Antennae and arista black, palpi fulvous. Thorax soft deep black, with a golden brown shade in oblique lights, humeri and pleurae cream colored, or silvery with a slight golden shade. Scutellum wholly black. Abdomen black, second segment with a median vitta and a narrow anterior border silvery pollinose with a slight golden shade, the border widening laterally; third segment same, but with the pollinose border more widened and laterally reaching the posterior border of segment, thus leaving on the posterior half of the segment an irregular black area on each side of the pollinose median vitta; anal segment entirely pollinose. First segment with a median marginal pair of bristles, second with a median marginal and discal pair, third and anal segments each with a somewhat irregular discal and marginal row of weak macrochaetae. Legs black; claws and pulvilli short in $q$, a little elongate in $\delta$. Wings hyaline, slightly grayish; tegulae tawny yellowish, halteres pale fulvous.

There seems to be little difference between the sexes, the $\hat{\delta}$ having the claws a little elongate while there is no appreciable difference in width of front. Described from three specimens, 2 \% and I $\delta$, Hanover, N. H., from Dr. C. M. Weed; and 2 오, Franconia, N. H., from Mrs. A. T. Slosson. I have seen this peculiar fly as yet only from New Hampshire.

Note. - Since sending the above in for publication, I have found in a sending from Mr. C. W. Johnson, of Philadelphia, two more specimens of this fly. One of these is a $\delta$, from Franconia, N. H., collected by Mrs. Slosson. The other specimen is from Montgomery County, Pennsylvania, and was collected July I 7 . 

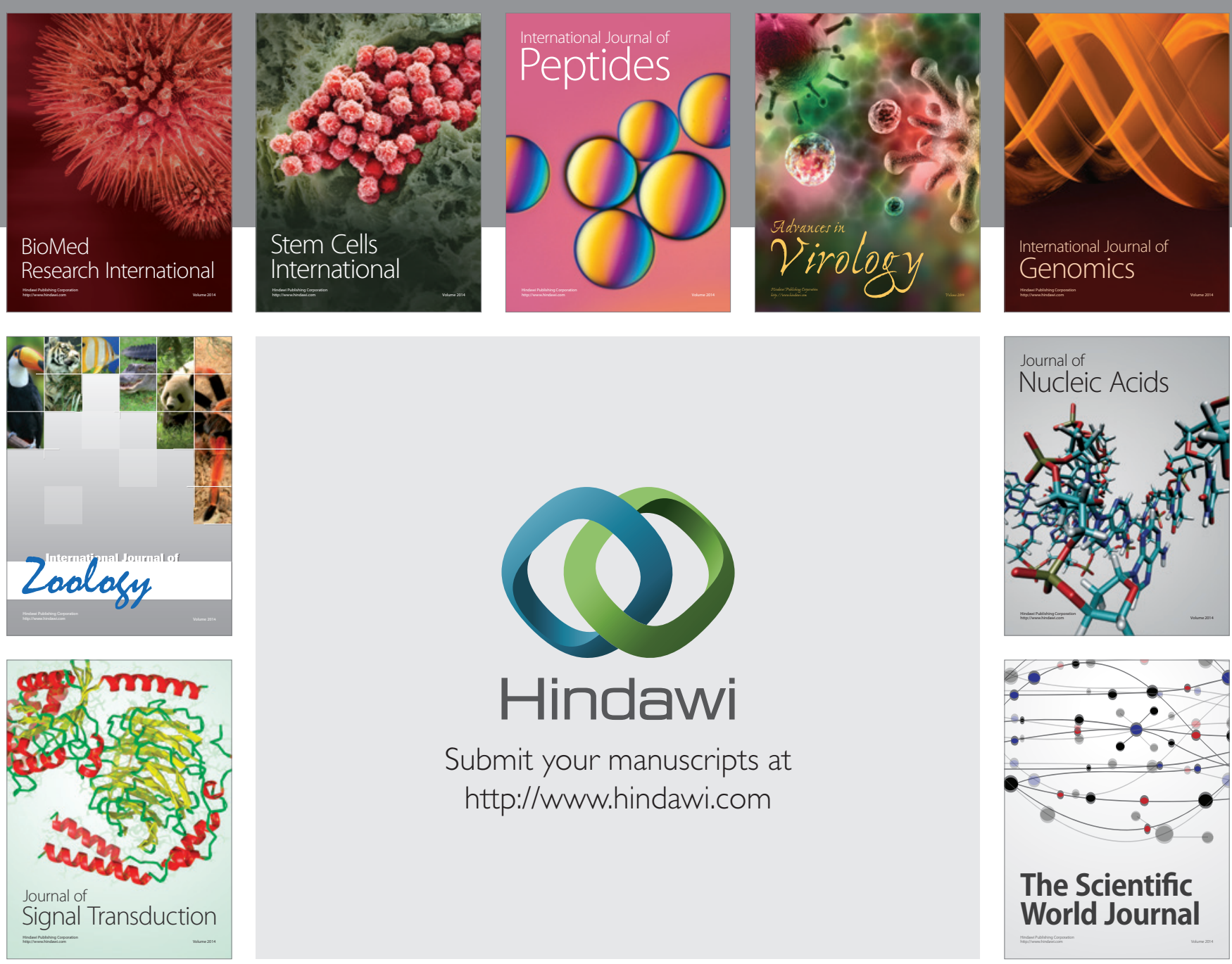

Submit your manuscripts at

http://www.hindawi.com
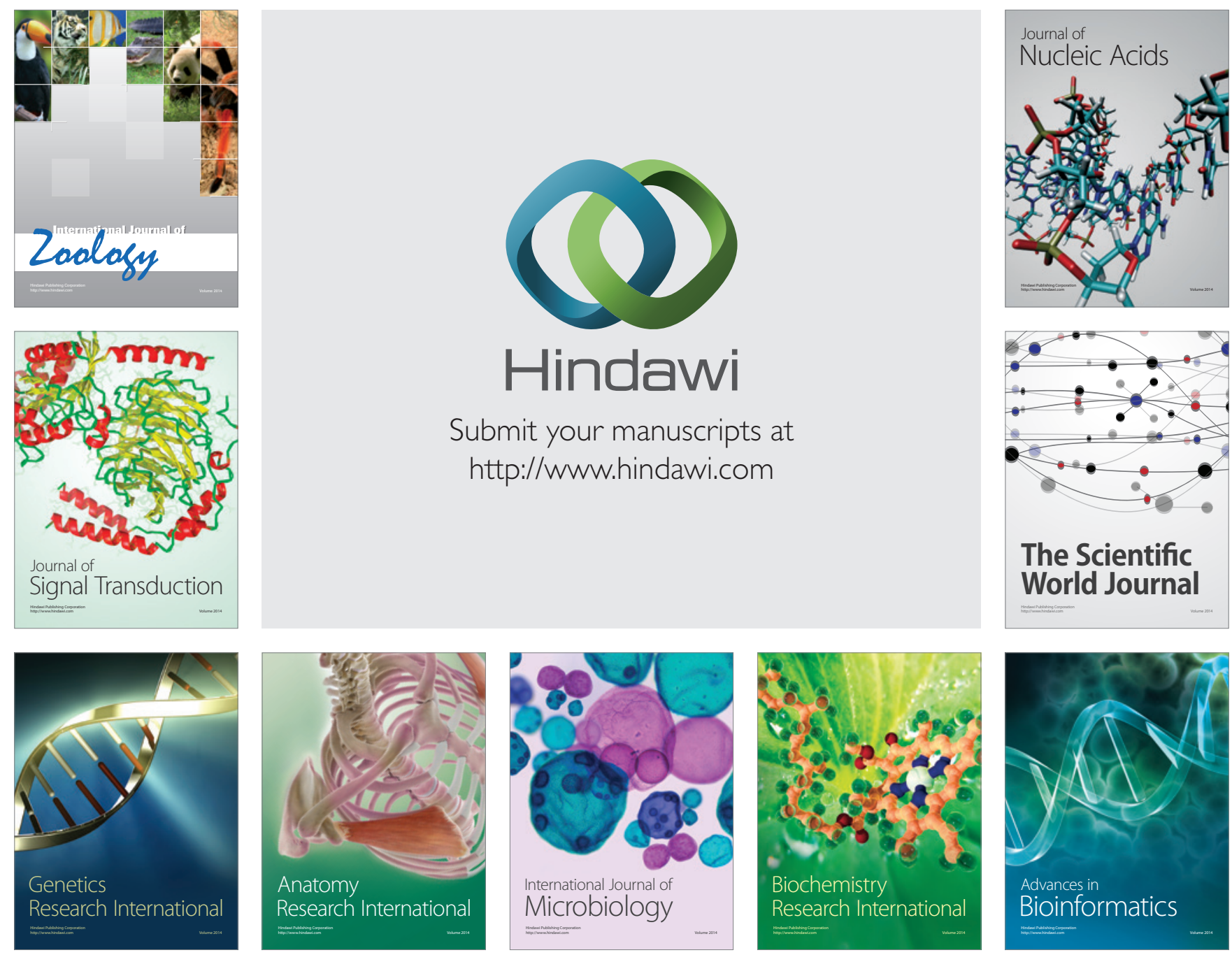

The Scientific World Journal
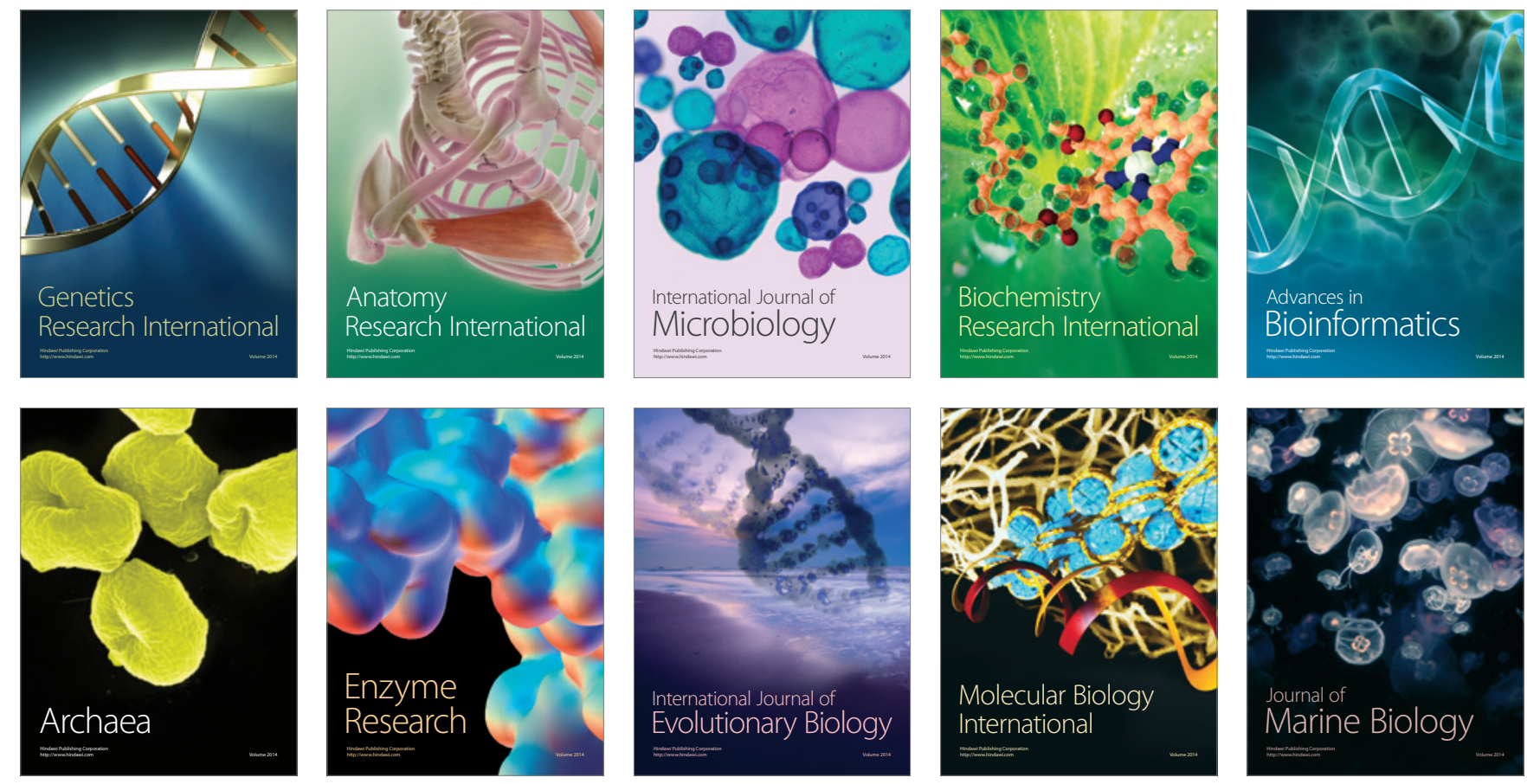